\title{
Who votes for new parties? Economic voting, political ideology and populist attitudes
}

\section{Hugo Marcos-Marne, Carolina Plaza-Colodro \& Tina Freyburg}

To cite this article: Hugo Marcos-Marne, Carolina Plaza-Colodro \& Tina Freyburg (2019): Who votes for new parties? Economic voting, political ideology and populist attitudes, West European Politics, DOI: 10.1080/01402382.2019.1608752

To link to this article: https://doi.org/10.1080/01402382.2019.1608752

View supplementary material $\circlearrowright$

Published online: 07 Jun 2019.

Submit your article to this journal $\sqsubset$

View Crossmark data ¿ 


\title{
Who votes for new parties? Economic voting, political ideology and populist attitudes
}

\author{
Hugo Marcos-Marne ${ }^{a}$ (D), Carolina Plaza-Colodro ${ }^{b}$ (D) and \\ Tina Freyburg ${ }^{\mathrm{a}}$ \\ ${ }^{a}$ School of Economics and Political Science, University of St.Gallen, St.Gallen, \\ Switzerland; ${ }^{\text {b}}$ Facultad de Derecho, Universidad de Salamanca, Salamanca, Spain
}

\begin{abstract}
Beginning with the economic crisis in 2008, a number of European societies witnessed the emergence of 'new parties'. Most authors explain their electoral appeal by focusing on how the perceived state of the economy influences individuals' voting decisions. This article determines the extent to which political attitudes can also explain voting for new political parties born in the heat of the economic crisis. Specifically, it explores the link between populist attitudes, in contrast to pluralist and elitist attitudes, and voting for two new political parties in Spain (Ciudadanos; Podemos), which are noticeably different in their ideological positions, programmatic proposals and populist discourses. The results show that stronger populist attitudes increase the likelihood of voting for new parties as dissimilar as Podemos and Ciudadanos. Overall, the findings suggest that voting for new parties cannot be understood as a mere economic response. Rather, political factors, and especially populist attitudes, matter too.
\end{abstract}

KEYWORDS Populism; populist attitudes; new political parties; economic voting; economic crisis; Spain

It is common ground in the literature that the 2008 economic crisis led to a political crisis (Beissinger et al. 2014), which has profoundly destabilised party systems in Europe in general, and in Southern Europe in particular (Hernández and Kriesi 2016; Kriesi 2014). Among its most visible consequences have been the new parties that entered into electoral competition, challenging the traditional mainstream parties (Hobolt and Tilley 2016; Kriesi 2014). While the ideological roots of these new parties differ substantially, their emergence seems to have had a similar effect across Europe: centre-left social democrats and centre-right Christian democrats, who have

CONTACT Hugo Marcos-Marne hugo.marcosmarne@unisg.ch

(7) Supplemental data for this article can be accessed online at: https://doi.org/10.1080/01402382. 2019.1608752

The corresponding replication material is available at www.tina-freyburg.eu.

(C) 2019 Informa UK Limited, trading as Taylor \& Francis Group 
dominated national politics for about 60 years, are in decline. How can this support for new political parties in times of economic crisis be explained?

So far, variants of the economic voting theorem have dominated the debate on why people voted for new political parties after the crisis (Bosch and Duran 2017; Hobolt and Tilley 2016; Orriols and Cordero 2016). Here, citizens are said to cast their vote largely in response to their evaluation of how the economy has performed since the last election. We concur with Torcal (2014) in arguing that, at first glance, the basic electoral behaviour patterns in countries such as Spain, Ireland and Portugal may appear to support the economic voting theorem; upon closer examination, however, it turns out that voters' ideological predispositions condition their evaluation of the economic situation and their final electoral decisions (cf. Fraile and Lewis-Beck 2010; Pattie and Johnston 2001).

Existing studies define the ideological predispositions of individuals in terms of their location on the left-right spectrum, that is a 'thick' understanding of political ideology. We, in turn, focus on voters' attitudes toward populism - a 'thin' ideology (Mudde 2004; Stanley 2008), which is commonly seen as providing an alternative notion of democracy in opposition to a liberal-pluralist as well as an elitist one (Akkerman et al. 2014; Mudde 2004). In essence, we explore whether new parties, populist or not, are primarily elected by citizens with populist attitudes (juxtaposed against pluralist and elitist attitudes). ${ }^{1}$ Our ambition is not to clarify the potentially endogenous relationship between 'thin' political ideology and economic assessment. Rather, we are interested in determining the extent to which voting for new parties in post-crisis Europe is essentially triggered by individuals' 'populist-oriented' concerns in light of caveats associated with liberal-democratic representation.

Overall, we deal with the political-attitudinal links between new parties and voters in the context of a crisis of representation that, accentuated by the economic crisis, challenges national party systems, in particular traditional two-party systems in Europe. In line with Mair (2011), we see the diminishing capacity of incumbent governments to simultaneously exercise the core functions of any liberal democracy - namely, to represent and respond to the demands of their voters, on the one hand, and to govern and effectively address cross-national challenges, on the other (see Dahl 1994) - as having led to a crisis of representation. While Mair referred predominantly to the general phenomenon that institutions such as international treaties, agencies and organisations (notably central banks, courts and the European Union) increasingly tie a national government's hands, the transnational economic crisis has amplified this tendency, especially in countries working through international rescue programmes, such as Greece, Portugal and Spain (Bosco and Verney 
2016). As a result, the crisis of representation, accentuated by the economic crisis, can involve the dissolution of the socio-electoral links between ruling mainstream parties and their electorates.

Empirically, we study the relationship between populist attitudes and the intention to vote for new parties in post-crisis elections using data from a representative survey among 1208 respondents in Spain, which we conducted online between 11 and 17 December 2015, i.e. shortly before the general national elections on 20 December. With the consolidation of two new political parties - one on the left (Podemos), the other on the right (Ciudadanos) of the political-ideological axis - the 2015 elections of the Spanish parliament ended decades of two-party domination. Studying the political attitudes of individuals, who intend to vote for new but ideologically different parties within a single country, allows us to determine the effect of populist attitudes independently and in interaction with political ideology, keeping contextual influences constant. We expect our argument to be applicable to similar contexts affected by political-economic crises.

Our findings support that voting for new parties is not merely determined by citizens' economic assessments, but crucially also by the extent to which they share populist attitudes. The leftist populist party Podemos is primarily selected by individuals with strong populist attitudes or by individuals with a left-wing ideology; the centre-right party Ciudadanos tends to be chosen by populist individuals that also share a rightwing ideology.

This article is organised as follows. In the first section, we briefly discuss the puzzle of support for new but programmatically different parties in times of political and economic crisis. Subsequently, we develop our argument linking the intention to vote for new political parties and populist attitudes. Thereafter, we present the research design and the empirical analysis of our original survey data. Our results suggest that the effects of the economic crisis considerably challenged notions of representation in European societies, making populism a viable response and a predictor of voting intention for new parties with otherwise different electoral platforms. Given the stability of political attitudes (Albarracin and Shavitt 2018), and contrary to common wisdom, the survival of the new parties may not necessarily be conditional on the continuation of poor domestic economic performance.

\section{Support for new but programmatically different parties}

The rise and initial success of new political parties in established democracies (including green and new right and left parties but also new religious parties and a range of single-issue parties) is a striking 
phenomenon that has been observed even before the latest economic crisis (Bolleyer 2013). One of the few attempts to provide a comprehensive account of the emergence of new parties is the theory of strategic entry, as developed by Cox (1997) and adapted by Tavits (2006). According to Cox's (1997: 161-70) theoretical analysis, the emergence of a new party results from the strategic calculations of elites regarding whether or not to enter the electoral arena. Next to the anticipated 'costs of entry' and 'benefits of holding office', this decision is, arguably, decisively influenced by the 'probability of getting electoral support', that is the elite's estimation of the chance to attract votes (Tavits 2006: 102-4). Expectations should look more favourable if voters - frustrated with the performance of mainstream parties - seem willing to turn to new parties promising change (Lago and Martinez 2011).

Indeed, the probability of getting support increases for new parties in tandem with the inability of traditional parties to respond adequately to citizens' demands. In their efforts to explore the erosion of the links between parties and voters, existing studies build upon explanations based on structural change and political-economic crisis (Kitschelt 1988: 196). Structure-based explanations focus on medium- to long-term societal transformation bearing new issues and new conflict lines. In response to structural change, citizens generate new preferences which are not (and maybe also cannot be) adequately addressed by existing institutions. Examples are Herbert Kitschelt's (1988) study of the emergence of green and left-libertarian parties due to value change, or Hanspeter Kriesi et al.'s (2008) work on the rise of right-wing populist parties linked to processes of denationalisation. The key point underlining these efforts to explain the emergence of new parties is 'a changing electorate and an unresponsive party system' (Hawkins et al. 2017: 272).

Explanations featuring (political-)economic crises, in turn, emphasise the short-term effect of societal strains and relative deprivation on citizens that, in reaction, blame existing institutions for poor performance. The most prominent crisis-related explanation may be the economic voting theorem. Its main idea is depicted by the 'responsibility hypothesis', according to which voters pick candidates on the basis of their perceived economic performance. Incumbents who have presided over economic prosperity are rewarded at the polls, while those who are deemed responsible for decline are punished (Lewis-Beck 1986; LewisBeck and Paldam 2000). Citizens can electorally punish a party for economic decline by not voting for it, whether by abstaining or by voting for another party. These may be parties that had already been in opposition, existing but previously marginal parties, or newly emerging parties. 
Studies of voting behaviour demonstrate that, in times of crisis, citizens use their vote to protest (Kriesi 2014). The literature also shows that parties expressing anti-establishment and other ideologically extreme positions benefit in difficult times, whether they already existed but were previously marginal, or have only newly entered the electoral field (Bosco and Verney 2016; van der Eijk and Franklin 1996). In short, vote choices are said to be primarily influenced by a combination of (economic) dissatisfaction with previously selected parties and the perceived viability of their alternatives (Kang 2004).

Notwithstanding their prominence, crisis-focused explanations on their own cannot adequately explain the emergence and also the, at least initial, electoral success of new but programmatically different parties after the recent European economic crisis (Kriesi 2014). While it is tempting to draw a direct link between the economic crisis and voting for new parties, such a crisis might also catalyse pre-existent dynamics of detachment in voters' relations with mainstream parties. Although punishing the incumbent party is well predicted by economic voting, we know little about why some citizens turn to new parties instead of abstaining or supporting already existing (opposition) parties.

\section{The attitudinal dimension of voting for new parties}

In searching for an answer as to who votes for new parties, and without overlooking the importance of economic assessments, we argue that a more complete explanation needs to include political-attitudinal aspects and, in particular, populist attitudes. Existing studies featuring political attitudes tend to either concentrate on a citizen's placement on the political left-right spectrum when studying voting for new parties (Fraile and Lewis-Beck 2010; Pattie and Johnston 2001; Torcal 2014; Vidal 2018), or focus on populist parties when examining voters' populist attitudes (Van Hauwaert and Van Kessel 2018). ${ }^{2}$ We determine the effect of populist attitudes on voting for parties that claim to stand for cutting ties with traditional elites, but are not necessarily populist.

In defining populist attitudes, we recognise that populism represents a distinct set of ideas. We draw on the standard definition of populism that centres on the ideological traits of this phenomenon (Hawkins et al. 2012; Hawkins, Carlin, et al. 2018; Mudde 2004; Mudde and Rovira Kaltwasser 2013). According to this minimal definition, populism is a set of ideas that considers society to be ultimately separated into two homogenous and antagonistic groups, 'the pure people' and the 'corrupt elite', and argues that politics should be an expression of the general will of the people (people-centrism). As a pre-existing set of specific ideas, populist 
attitudes must be activated by political actors in a context of (perceived) 'policy failures that can be traced to systematic malfeasance by traditional politicians' (Hawkins et al. 2017: 277).

According to the structural change explanation, prior to the economic crisis populist attitudes could be widely spread with no electoral consequences, as long as they were not activated in a context in which populist reactions were credible. The 2008 crash provided the opportunity for such electoral activation of populist attitudes. However, it is not the only reason for the deep discontent with liberal-representative democracies among parts of the citizenry. Rather, in times of political crisis, individuals with populist attitudes might turn to new political parties promising a 'real' alternative to the establishment.

Our focus on political attitudes is thus motivated by the insight that if liberal-representative democracy is perceived by citizens not to be working, they will turn to alternative concepts of democracy that promise to overcome the identified shortcomings in responsiveness. Crucially, populism is often presented as having the potential to act as a corrective to liberal democracy (Rovira Kaltwasser 2012). In particular, the populist critique of the ruling elite might be reflected in citizens feeling alienated from the 'goings-on' in politics, such as keeping certain issues off the public agenda for pragmatic or ideological reasons (Hawkins et al. 2017: 277). Plus, the populist alleged 'return to the people' - be it the sovereign, the nation, or a certain social class (Canovan 2004) - may be interpreted by some citizens as a reasonable answer to the (perceived) crisis of representation.

Yet, populist attitudes do not necessarily only benefit populist parties. In contrast to modern 'thick' political ideologies such as conservatism or socialism, populism (as a 'thin' ideology) does not necessarily prescribe comprehensive issue positions and can coexist with traditional ideologies (Aslanidis 2016; Mudde 2004: 544). Populist ideas can thus be shared by individuals who otherwise adhere to different 'thick' political ideologies. And populist discourses can bring together populist parties with populist electorates, even if party and electorate disagree on the 'thick' substance of policy proposals (Van Hauwaert and Van Kessel 2018). Yet this capacity decreases the more strongly the policy ideas of party and potential voter differ (Andreadis et al. 2018; Hawkins, Kaltwasser, et al. 2018). Against this, it seems unlikely that (even whole-hearted) populists would support a populist party if they fundamentally disagreed with the party's policy proposals.

Instead, these citizens with strong populist attitudes may feel inclined to support a new party that shares their policy preferences, in particular if that new party presents views on democratic decision-making processes 
deviating from the status quo and puts these at the forefront of its political programme. Accordingly, we conclude that individuals who display populist attitudes may interpret the novelty and general anti-mainstream nature of new parties as promising change in times of crisis - and express their intention to vote for such parties even if they do not necessarily and consistently utilise populist discourses. It is in this sense that voting for new parties by individuals with populist attitudes can be considered as an answer to the crisis of representation that has been worsened by the economic crisis. Based on these insights, we seek to empirically test whether the strength of populist attitudes is positively associated with the likelihood of voting for new political parties, as stated by our first hypothesis.

H1 (populist attitudes): The stronger the populist attitudes of a citizen are, the more likely he or she intends to vote for a new political party.

Having said this, there is reason to caution against 'reduc[ing] the success of political newcomers to their populist appeals' (Bornschier 2017). Eventually, 'studies of many electoral contexts find that left-right ideology ranks as one of - if not the - largest determinants of party choice' (Hellwig 2008: 687). As Kriesi (2014: 369) discusses, the social-structural grievances on which populist parties tend to mobilise can be more closely related to their positioning on the political left-right axis, rather than to core features of populism. This does not present a problem for our study, predominantly for two reasons: first, we centre on populist attitudes of individual citizens, rather than the populist nature of new parties; and second, we are primarily concerned with estimating the extent to which these attitudes can explain intentions to vote for new parties of varying ideologies. Still, the relevance of the relation between 'thick' and 'thin' ideologies in voting for new parties needs to be empirically assessed.

To this end, we draw on Van Hauwaert and Van Kessel's work (2018), which suggests that individuals with strong populist attitudes might vote for a populist party even if there is no perfect individual-party congruence in policy preferences. Here, populist attitudes behave as a 'motivational substitute', explaining voting for populist parties when policy incongruences exist. However, recent studies highlight that the capacity of populism to bring together parties and voters is not without limits. Hawkins, Carlin, et al. (2018) and Andreadis et al. (2018) point out that populist attitudes better explain voting for populist parties when policy preferences are not too distant.

Given the sensitivity of both populist and left-right ideologies to the economic situation, it seems reasonable to expect that the link between populist attitudes and vote choice is conditioned by an individual's ideological location on the left-right scale. This is especially the case since our theoretical framework refers to new political parties that are not 
necessarily populist. Hence, we expect citizens' positions on the left-right ideological scale to determine if they intend to vote for a new party, and - when several new parties are available with different ideological profiles - for what new party, as stated in our second hypothesis, complementing Hypothesis 1:

H2 (thick-thin ideology): Given that options are available, a citizen with populist attitudes is more likely to intend to vote for the new party that corresponds best to his or her position on the political left-right spectrum.

In order to improve our analysis, we follow Akkerman et al. (2014) in conceptually and empirically contrasting populist attitudes to what they are not, namely pluralist and elitist attitudes. Specifically, populists are defined as opposed to key features and institutions of pluralist, heterogeneous society, such as compromise, mediation and minority rights. As regards the second antipodal concept, elitists share the Manichean division between the people and the elite but assign the opposite attributes to each societal group, that is 'the elite' is seen as pure and virtuous and 'the people' as corrupt.

While 'there is no theoretical reason for these ... [concepts] to be mutually exclusive' (Akkerman et al. 2014: 1336; cf. Hawkins et al. 2012), contrasting populist attitudes with pluralist and elitist attitudes is in line with the theoretical idea that a true populist is one who supports things that refer to the core aspects of populism, and rejects their logical opposites. We would expect pluralist citizens, who appreciate the diversity of opinions and accept democratic decisions as compromises, to be less inclined to vote for new anti-establishment parties striving 'towards the replacement of the existing pluralist society and democratic system with one that is better suited for the achievement of their radical transformative objectives' (Gunther and Diamond 2003: 178). This should hold especially true for (new) populist parties proclaiming a uniform 'people', that largely share the same interests and (cultural/ economic) features.

Likewise, elitist citizens, who see elites as being better able to make the right policy decisions (because they are better educated, better socialised into the give-and-take of democratic politics, equipped with a disproportionate degree of expertise, etc.), should be less likely to vote for new parties that tend to present themselves as the alternative to established parties and the ruling elite. Again, this effect should be stronger for populist new parties explicitly rejecting the ruling elite as corrupt, unrepresentative, unresponsive and incompetent (if not 'undemocratic'). This reasoning culminates in the formulation of our third hypothesis on the link between voting for new parties and elitist and pluralist attitudes, respectively. 
H3 (elitist/pluralist attitudes): The stronger the elitist or pluralist attitudes, respectively, of a citizen are, the less likely it is that he or she intends to vote for a new political party. This effect should be stronger for populist new parties.

\section{Case study design}

We explore the link between political attitudes, notably populist attitudes and their antipodes, and voting intentions for new parties in post-crisis Spain. Building upon a 'typical case' research design (Seawright and Gerring 2008: 299-300), we chose Spain based upon a set of causally relevant descriptive characteristics that allows us to test the hypothesised link with the potential to explain vote intentions for new parties across postcrisis European democracies. The economic and political impact of the crisis in Spain, though intense, was not exceptional, and was similar to a number of other European societies (Hernández and Kriesi 2016: 206; Hobolt and Tilley 2016: 972).

In all severely crisis-affected economies that have been, or are still, subject to interventions by the Troika, the traditional mainstream parties are in decline. In many of them new anti-establishment parties arose, including the 'Five Star Movement' (M5S) in Italy and the 'Bright Future' in Iceland. Like Greece, where the mainstream parties faced headwind from both the left (notably the Coalition of the Radical Left Syriza) and the right (e.g. the right-wing ANEL), Spain witnessed the emergence of two new political parties with distinct ideological platforms; yet the new Spanish party on the left, Podemos, has not electorally outplayed the new party on the right, Ciudadanos, as much as Syriza did in Greece. Overall, the Spanish case allows for exploring the causal mechanism of interest within one single case, controlling for potential alternative influences, and identifying 'cross-case'-mechanisms of vote intention for new parties, focusing on populist attitudes.

In Spain, over the past three decades, combined support for the conservative 'People's Party' (PP) and the centre-left 'Socialist Workers' Party' (PSOE) often exceeded $70 \%$ of the total vote and $80 \%$ of the seats in the parliament. In the 2015 post-crisis elections, the PP-PSOE joint vote dropped to $50 \%$, as new electoral spaces were occupied by new or previously marginal parties. In a context of activated populist competition (Andreadis et al. 2018; Hawkins et al. 2017: 276), two new but programmatically different parties entered the national electoral competition. Podemos received $21 \%$ of the vote and became the third largest party in the parliament, and also Ciudadanos entered the parliament with $14 \%$ of the vote. 
Both new parties claim to present a break with traditional elites, but substantially differ with regard to their respective location on the leftright spectrum, centre-periphery positions, and in the extent to which they can be seen as populist. Ciudadanos is considered a centre-right party that emphasises gradual transformation, although anti-elite claims also appear in its political discourse (Sola and Rendueles 2018). Podemos, in turn, is much more pro-periphery (Rodon and Hierro 2016), it displays an evidently more populist discourse (Marcos-Marne et al. 2017), and is usually defined as a radical-left populist party (Lavezzolo and Ramiro 2017; Sola and Rendueles 2018).

Podemos and Ciudadanos voters have been characterised as fundamentally different in their positions on right-left political issues and territorial preferences (Orriols and Cordero 2016), too. At the same time, they also share some important features, including their relatively young age, their dissatisfaction with political institutions and in their more negative assessment of the economic situation (Bosch and Duran 2017; Rodon and Hierro 2016; Vidal 2018).

\section{Data and variables}

Our data come from an original survey that was implemented online by the company Netquest shortly before the general elections in December 2015. To avoid bias in the distribution of age, gender, professional background and territorial distribution of respondents, the 1208 respondents were selected using quota sampling (see Table OA.1 in the Online Appendix).

Our dependent variable is a binary measure of vote intention, operationalised as the answer to the following question: 'Could you tell us which party will you vote for in the general elections on 20 December?'. 3 We concentrate on those respondents who, despite potential anti-elite attitudes, still value the institutionalised electoral process and know (or are willing to state) their electoral preferences. To this end, we selected only respondents that declare an intention to vote for any political party $(N=789)$ and discard those that did not answer, did not know yet what party to vote for, or intended to abstain. We coded the intention to vote for Ciudadanos or Podemos as '1', and '0' otherwise. Podemos participated in the 2015 general elections in coalition with other political forces in three 'autonomous communities' (Valencia, Galicia and Catalonia); we consider the vote intentions jointly under the label 'Podemos'.

In order to measure our three key independent variables, that is populist, elitist and pluralist attitudes, we utilise a set of 11 item statements (see Table 1), which present the current standard in measuring populist 
Table 1. Scale properties of items tapping political attitudes in Spain, 2015.

\begin{tabular}{|c|c|c|c|}
\hline & $\begin{array}{l}\text { Populism } \\
\text { (POP) }\end{array}$ & $\begin{array}{c}\text { Elitism } \\
\text { (ELI) }\end{array}$ & $\begin{array}{c}\text { Pluralism } \\
\text { (PLU) }\end{array}$ \\
\hline $\begin{array}{l}\text { POP1: 'The politicians in the Spanish parliament need to follow } \\
\text { the will of the people' }\end{array}$ & 0.32 & -0.09 & 0.33 \\
\hline $\begin{array}{l}\text { POP2: 'The people, and not politicians, should make our most } \\
\text { important policy decisions' }\end{array}$ & 0.57 & -0.22 & 0.11 \\
\hline $\begin{array}{l}\text { POP3: 'The political differences between the elite and the people } \\
\text { are larger than the differences among the people' }\end{array}$ & 0.47 & -0.11 & 0.20 \\
\hline $\begin{array}{l}\text { POP4: 'I would rather be represented by a citizen than by a } \\
\text { specialised politician' }\end{array}$ & 0.66 & -0.17 & -0.11 \\
\hline POP5: 'Elected officials talk too much and take too little action' & 0.68 & 0.07 & 0.08 \\
\hline $\begin{array}{l}\text { POP6: 'What people call "compromise" in politics is really just } \\
\text { selling out on one's principles' }\end{array}$ & 0.60 & 0.23 & -0.04 \\
\hline $\begin{array}{l}\text { ELI1: 'Common people cannot be trusted to take the right } \\
\text { decisions about a country's problems' }\end{array}$ & -0.10 & 0.61 & -0.05 \\
\hline ELI2: 'Politicians should lead rather than follow the people' & -0.07 & 0.60 & 0.10 \\
\hline $\begin{array}{l}\text { ELI3: 'Our country would be governed better if important } \\
\text { decisions were left up to independent experts' }\end{array}$ & 0.36 & 0.46 & 0.05 \\
\hline $\begin{array}{l}\text { PLU1: 'In a democracy it is important to make compromises } \\
\text { among differing viewpoints' }\end{array}$ & -0.03 & 0.07 & 0.84 \\
\hline PLU2: 'It is important to listen to the opinion of other groups' & 0.03 & -0.05 & 0.82 \\
\hline SS Loadings & 2.07 & 1.11 & 1.58 \\
\hline Variance explained (\%) & 19 & 10 & 14 \\
\hline
\end{tabular}

Note: Factor analysis with Eigenvalues $\geq 1.0$ extracted; Oblimin rotation; factor loadings $>0.40$ are displayed in bold; $N=789$.

attitudes from an ideational perspective, and its two antipodal meanings. For each of the three dimensions, we select those items included in the scales originally proposed by Akkerman et al. (2014: 1331). ${ }^{4}$ Respondents were asked to rate their agreement with each item on a Likert scale ranging from 1 ('I very much disagree') to 5 ('I very much agree'). A factor analysis was conducted to construct three factors with an Eigenvalue equal to or larger than 1 (see Table 1). These factors correspond to the dimensions developed by Hawkins et al. (2012) and Akkerman et al. (2014), sustaining our measurement empirically and theoretically (Worthington and Whittaker 2006). We enter the scores obtained from these factors (Bartlett scores, see Di Stefano et al. 2009) in the analysis as independent variables measuring (latent) populist, elitist and pluralist attitudes. ${ }^{5}$

The factors identified have a satisfactory internal consistency, as corroborated by their internal reliability. Cronbach's alpha for the populist dimension is $\alpha=0.76$, for the elitist dimension $\alpha=0.54$, and for the pluralist dimension $\alpha=0.81$. $^{6}$ Although correlation between the three factors demonstrates that the three dimensions of political attitudes present factors on their own, populist attitudes are positively correlated with pluralist attitudes $[\mathrm{r}(787)=0.25, p<0.00]$, and negatively with elitist attitudes $[\mathrm{r}(787)=-0.09, p<0.00)$, whereas elitist attitudes are not significantly correlated with pluralist attitudes at $p<0.05$. The positive and statistically significant correlation between the populist and pluralist scales 
is predominantly driven by the cross-loadings of the first and third items (POP1; POP3), indicating that at least some individuals with pluralist attitudes are also highly critical of elected politicians (see Akkerman et al. 2014: 1336).

We are confident that our measurement adequately captures individuals' populist attitudes. First, we use the theoretically grounded definition of political attitudes developed by Akkerman et al. (2014) and, by applying their measure of political attitudes to the Spanish case, we also put the validity of this popular set of items to an additional test. Second, our populism indicators have been demonstrated to effectively capture in particular the people-centred dimension of populism (Spruyt et al. 2016: 340), which largely differs from mere protest or general dissatisfaction. Third, and in addition to conceptual considerations, other studies using similar indicators have found strong empirical evidence that populist ideas, although connected to distrust or discontent, present an independent variable (Spruyt et al. 2016; Van Hauwaert and Van Kessel 2018). Even though we cannot preclude with absolute certainty that what we call populist attitudes are not affected by other attitudinal preferences, we are confident that populism indeed presents a distinct theoretical construct.

In addition to the three fundamental political attitudes' variables (populist, elitist, pluralist), we include a number of control variables. Drawing on the existing literature, the chosen covariates refer to the personal and general assessments of the economic situation, left-right ideology, as well as the standard set of socio-demographic variables, namely age, gender, education, employment status and income (for descriptive statistics and survey questions, see Table OA.3). Since economic and cultural ideological elements highly correlate in Spain, we use an unidimensional indicator of ideology (Vidal 2018: 264 and 273). All nondichotomous variables have been standardised prior to running the regression analyses (Di Stefano et al. 2009: 5-6). Given our relatively small sample size $(N=705),{ }^{7}$ we present marginal effects, instead of odd ratios, to make the interpretation more reliable (Bertgold et al. 2018).

In a previous study, Andreadis et al. (2018) find a link between (activated) populist attitudes and voting for both new parties in Spain, Podemos and Ciudadanos, albeit the latter cannot really be classified as populist. We refine and challenge their analysis in three important ways. First, we apply a threedimensional measurement of political attitudes that allows for distinguishing between populist, pluralist and elitist attitudes. Second, we compare potential Ciudadanos and Podemos voters to all other voters, and not only to those of the PP, whose voters happen to be the least populist in our sample (Table OA.4). ${ }^{8}$ Finally, we control for additional properties of individuals that may affect vote decisions, such as subjective perception of the economic crisis and personal income. 
Table 2. Political attitudes and voting for new parties in Spain, 2015.

\begin{tabular}{|c|c|c|}
\hline & Model 1 & Model 2 \\
\hline \multicolumn{3}{|l|}{ Political attitudes } \\
\hline Populism & $0.09 * * *(0.02)$ & $0.07 * * *(0.02)$ \\
\hline Elitism & $-0.03(0.01)$ & $-0.00(0.01)$ \\
\hline Pluralism & $0.00(0.01)$ & $0.00(0.02)$ \\
\hline \multicolumn{3}{|l|}{ Controls } \\
\hline Left-right ideology & & $-0.03(0.02)$ \\
\hline Female $(=1)$ & & $-0.15^{* * *}(0.04)$ \\
\hline Age (years) & & $-0.12^{* * *}(0.02)$ \\
\hline Education & & $0.02(0.02)$ \\
\hline Economy: sociotropic assessment & & $0.05^{* *}(0.02)$ \\
\hline Economy: egotropic assessment & & $-0.00(0.02)$ \\
\hline Unemployed $(=1)$ & & $0.08(0.07)$ \\
\hline Income & & $0.00(0.02)$ \\
\hline pseudo $R^{2}$ (Nagelkerke) & 0.07 & 0.16 \\
\hline
\end{tabular}

Note: Entries are average marginal effects (binary logistic regression), with standard errors in brackets; ${ }^{* *} p<0.05 ;{ }^{* * *} p<0.01$ (two-tailed), at $95 \%$ confidence level; $N=705$. Null deviance: 971.34 on 704 degrees of freedom. Residual deviance: 879.50 on 693 degrees of freedom.

\section{Empirical results}

Given the dichotomous nature of our dependent variable, we report the average marginal effects (AME). First, estimates and odds ratios normally reported suffer from important biases if there are omitted variables, even if these are not correlated to the covariates included; second, it is problematic to compare coefficients across models due to unobserved heterogeneity. AME represent the marginal effect of each covariate on the likelihood of intending to vote for a new party, averaged over the joint distribution of the remaining covariates. They therefore differ from traditional marginal effects that measure the impact of each covariate keeping all others constant. AME allow for a more realistic scenario, taking into account that the effect of one covariate may differ depending on the values of the other covariates, and they allow for comparisons across models (Mood 2010: 80).

Table 2 shows the average marginal effects of two binary logistic regression models with the intention to vote for a new political party as an outcome variable. Our findings support Hypothesis 1 on the link between populist attitudes and voting for new political parties, regardless of the degree to which the new party is populist in its discourse. The effect of populist attitudes on the intention to vote for new parties remains if a multinomial logistic regression is conducted, separating Ciudadanos and Podemos voters, respectively, from the voters of traditional parties. The achieved findings suggest that the results presented in Table 2 are not biased because more individuals declared their intention to vote for Podemos than Ciudadanos (see Table OA.5).

Turning to political ideology, the effect of self-positioning on the leftright spectrum has no significant effect in voting for new political parties. 

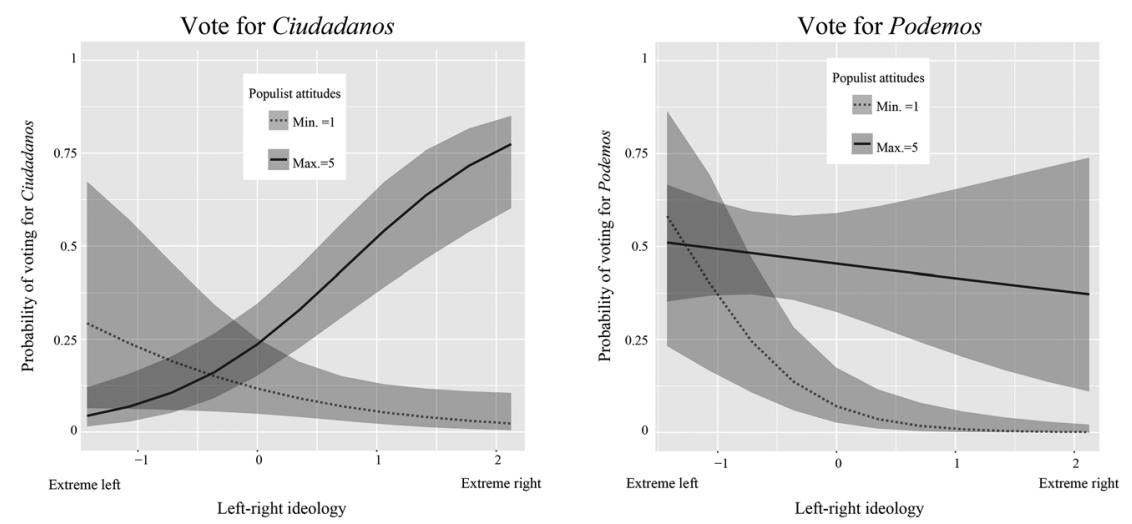

Figure 1. Predicting intention to vote for new parties in Spain, 2015.

This was expected since, on average, individuals located more on the left of the ideological spectrum are more likely to intend to vote for Podemos, and those located more on the right are more likely to intend to vote for Ciudadanos. Unsurprisingly, when both parties are jointly considered, ideology fails to explain why individuals prefer a new party rather than a traditional one. However, do we find evidence supporting the interaction effects between populist attitudes and political ideology on voting intention, as stated in Hypothesis 2?

For that, we run the regression models separately for respondents with the intention to vote for Ciudadanos $(N=504)$ and Podemos $(N=586)$, respectively. For example, in the model with the intention to vote for Ciudadanos as dependent variable, we excluded those respondents with the intention to vote for Podemos, in order to guarantee that the comparison is made between voters of new parties (here, Ciudadanos), and voters of traditional parties. If we consider specific placements on the left-right scale, a positive and statistically significant interaction term between left-right positions and populist attitudes is observed for Ciudadanos $[\beta=0.38, t(491)=3.34, p<0.01]$, and also for Podemos $[\beta=0.32, t(585)$ $=2.28, p<0.05$ ] (see Table OA.6).

Figure 1 shows how populist attitudes influence vote intentions for new parties in interaction with left-right ideology. It concentrates on the strongest and the lowest level of populist attitudes. It turns out that the likelihood of left- and right-leaning individuals with strong populist attitudes to intend to vote for Podemos is about the same. In line with Van Hauwaert and Van Kessel (2018), populist parties seem able to attract populist voters that do not fully share their 'thick' ideological positioning. Conversely, respondents with strong populist attitudes are less likely to intend to vote for Ciudadanos if they place themselves on the left side of the ideological scale. The more respondents move to the 
right, the greater the influence exerted by populist attitudes on the likelihood of voting for Ciudadanos. Therefore, and as expected, political-ideological congruence plays an important role in explaining why some populist individuals intend to vote for a non-populist new political party $(\mathrm{H} 2)$.

Regarding Hypothesis 3, we see that elitist and pluralist attitudes have no consistent effect on the intention to vote for new parties. If Ciudadanos and Podemos voters are compared separately to the rest of respondents (see Table O.A5), elitist attitudes are negatively associated with the intention to vote for Podemos, but not for Ciudadanos. It appears that individuals intending to vote for a new populist party (here: Podemos) better reflect an 'ideal' populist position than those who intend to vote for a new but non-populist party (here: Ciudadanos). The pluralism score, in turn, shows no significant effect on the intention to vote for either new political party, probably because pluralist views are widely shared among all respondent in our sample.

The observed effects hold when controlling for citizens' assessments of the economic situation. In line with Bosch and Duran (2017), our analyses suggest that economic matters also influence the success of both parties, with sociotropic evaluations being more important than egotropic ones. However, even controlling for both egotropic and sociotropic assessments of the economic situation, political attitudes still have an independent and robust effect on voting for new parties. These results suggest that the economic crisis is only one among multiple motives that make people vote for new political parties. Overall, we find reasons to argue that individuals aiming to vote for new parties in Spain share a concern regarding the responsiveness of traditional parties and their ability to effectively solve political problems. Populist attitudes, in particular people-centred preferences, can explain the intention to vote for new parties programmatically as different as Ciudadanos and Podemos.

\section{Conclusion}

It stands to reason that the emergence of new parties in the aftermath of an economic crisis is importantly driven by a change in individuals' assessments of their own and the country's economic situation. Yet prior ideological predispositions have been demonstrated as shaping how individuals perceive and evaluate the economic crisis, its causes and consequences. In this article, we have argued that 'thin' ideological predispositions (i.e. populist attitudes) can explain why some people vote for new parties, even when accounting for the role of political 'thick' 
ideology, and controlling for individual assessments of the economic situation. Specifically, we have suggested that the reason why populist attitudes influence intention to vote for new political parties with radically different platforms can be found in the intersection between the economic crisis and a deepening crisis of representation in democracies. Populist attitudes, with their anti-elite and people-centred components, can make citizens perceive new parties as a 'real' alternative beyond the alternance in power of traditional forces.

Considering intentions to vote for new parties in Spain in 2015, our empirical analysis of original survey data demonstrates that populist attitudes do indeed increase the likelihood of voting for new parties as different as Podemos and Ciudadanos. The interaction between populist attitudes, socio-demographic properties and their position on the political left-right spectrum can explain which of the two parties citizens intend to vote for. Overall, our study suggests that new political parties can connect with the electorate beyond the pure economic consequences of the crisis. Therefore, new parties might survive even in times of economic prosperity, although new challenges may appear in the form of institutionalisation problems or their ability to continuously mobilise on populist attitudes.

In light of the varying impact of right-left ideology on the likelihood of voting for Ciudadanos and Podemos, respectively, future research could seek to disentangle the profiles of the different electorates more thoroughly. This includes how different notions of 'the people' are influenced by 'thick' ideological positions at the individual level. It might be worthwhile to also study the extent to which populist attitudes can explain the gain or loss in votes of 'old' but hitherto marginal parties, which is also missing in our analysis. Finally, our results are supported by empirical material gathered in a single wave in Spain. Therefore, additional comparative studies may help in shedding light on the proposed connection between populist attitudes and voting for new political parties after the economic crisis.

\section{Notes}

1. Since we study new political parties, which do not necessarily utilise populist discourses, our study differs from those examining the electoral basis of populist parties (Rooduijn 2018; Van Hauwaert and Van Kessel 2018).

2. An exception is Lavezzolo and Ramiro's (2017) study of support for new parties based on voters' positions on the left-right spectrum and stealth democracy. They find that, conditional on their ideology, citizens with stealth-democratic attitudes (i.e. favouring efficiency and experts' involvement in politics) are less likely to vote for the pro-participatory Podemos and more likely to vote for the centre-right Ciudadanos. Though 
stealth democrats and populists are united in their anti-elitist views, the two concepts differ with regard to the second dimension of populism, peoplecentrism (Mohrenberg et al. 2017).

3. The original question in Spanish reads ¿Podrías decir a qué partido votarás en las elecciones generales del 20 de diciembre?'.

4. We use the items in the wording suggested by Akkerman et al. (2014) and only replace 'the Dutch parliament' with 'the Spanish parliament' in POP1. The Spanish version is available in Table OA.2.

5. The two items included in the pluralist factor are highly correlated $(>0.70)$ and relatively uncorrelated to the other items (Worthington and Whittaker 2006; Yong and Pearce 2013); we therefore see no reason not to use this two-item factor score in subsequent analyses (see Costello and Osborne 2005).

6. Cronbach's alpha test of reliability behaves slightly better than Akkerman et al.'s (2014) original results, in particular as regards the elitist and the pluralist dimensions.

7. Out of the 789 respondents who declared an intention to vote for a specific political party, 84 individuals declined to answer the personal income question included as control.

8. To compare the populist attitudes of individuals grouped by vote intention, we conducted a one-way ANOVA, which turned out significant at $p<0.01$ $[\mathrm{F}(4,675)=39.6, p=0.00]$. Post-hoc comparisons using the Tukey-HSD test indicated that average populist attitudes in voters of $P P(M=-0.76$, $\mathrm{SD}=1.08)$ were significantly lower than in voters of PSOE $(\mathrm{M}=-0.04$, $\mathrm{SD}=1.06)$, Podemos $(\mathrm{M}=0.48, \mathrm{SD}=0.94)$, Ciudadanos $(\mathrm{M}=-0.08$, $\mathrm{SD}=1.09)$, and Unidad Popular $(\mathrm{M}=0.48, \mathrm{SD}=0.81)$.

\section{Acknowledgements}

Previous versions of this paper were presented at the IPSA Conference in Poznan (2016) and the CES Conference in Glasgow (2017). We want to thank the journal's anonymous reviewers, Team Populism members Margarita Gomez-Reino, Kirk Hawkins and Ivan Llamazares, and the members of the Department of Political Science at the University of St.Gallen for their constructive insights; special thanks go to Sarah Engler, Martina Fuerrutter, Lisa Garbe, Karina Mross, Ciaran O'Flynn and Véronique Wavre. Hugo Marcos-Marne also thanks Blanca Ausin for her help and support.

\section{Disclosure statement}

No potential conflict of interest was reported by the authors.

\section{Notes on contributors}

Hugo Marcos-Marne is a postdoctoral research fellow at the Chair of Comparative Politics, University of St.Gallen. His research focuses on political behaviour, attitudes and national identities. He has published on these topics in the Journal of Ethnic and Migration Studies, Ethnicities, National Identities, 
Revista de Estudios Politicos, Revista Internacional de Sociologia and Revista Española de Ciencia Politica, among others. [hugo.marcosmarne@unisg.ch]

Carolina Plaza-Colodro is a PhD candidate at the University of Salamanca. Her research investigates the radical, populist and Eurosceptic reactions of political parties since the beginning of the Great Recession, with special emphasis on parties within the most financially affected countries. Her work has been published in Politics, Revista de Estudios Politicos and Revista Internacional de Sociologia, among others. [cplazaco@usal.es]

Tina Freyburg is Professor of Comparative Politics, University of St.Gallen. Among her interests are political attitudes, notably democratic and populist attitudes, and their determinants and effects. Her work appears in International Studies Quarterly, European Union Politics and the Journal of European Public Policy, among others. [tina.freyburg@unisg.ch]

\section{ORCID}

Hugo Marcos-Marne (D) http://orcid.org/0000-0001-7085-9572

Carolina Plaza-Colodro (D) http://orcid.org/0000-0002-9680-3590

Tina Freyburg (D) http://orcid.org/0000-0002-1042-9869

\section{References}

Akkerman, Agnes, Cas Mudde, and Andrej Zaslove (2014). 'How Populist Are the People? Measuring Populist Attitudes in Voters', Comparative Political Studies, 47:9, 1324-53.

Albarracin, Dolores, and Sharon Shavitt (2018). 'Attitudes and Attitude Change', Annual Review of Psychology, 4:69, 299-327.

Andreadis, Ioannis, Kirk Hawkins, Ivan Llamazares, Cristobal Rovira Kaltwasser, and Matthew Singer (2018). 'Conditional Populist Voting in Chile, Greece, Spain and Bolivia', in Kirk Hawkins, Ryan Carlin, Levente Littvay, and Cristobal Rovira Kaltwasser (eds.), The Ideational Approach to Populism: Concept, Theory, and Analysis. Oxford: Routledge, 238-78.

Aslanidis, Paris (2016). 'Is Populism an Ideology? A Refutation and a New Perspective', Political Studies, 64:1s, 88-104.

Beissinger, Mark, Gwendolyn Sasse, and Kurt Straif (2014). 'An End to "Patience"? The Great Recession and Economic Protest in Eastern Europe', in Larry Bartels and Nancy Bermeo (eds.), Mass Politics in Tough Times: Opinions, Votes and Protest in the Great Recession. Oxford: Oxford University Press, 334-70.

Bertgold, Jason, Elizabeth Yeager, and Allen Featherstone (2018). 'Inferences from Logistic Regression Models in the Presence of Small Samples, Rare Events, Nonlinearity, and Multicollinearity with Observational Data', Journal of Applied Statistics, 45:3, 528-46.

Bolleyer, Nicole (2013). New Parties in Old Party Systems: Persistence and Decline in Seventeen Democracies. Oxford: Oxford University Press. 
Bornschier, Simon (2017). 'Populist Mobilization Across Time and Space: An Introduction', Swiss Political Science Review, 23:4, 301-12.

Bosch, Agusti, and Ivan Duran (2017). 'How Does Economic Crisis Impel Emerging Parties on the Road to Elections? The Case of the Spanish Podemos and Ciudadanos', Party Politics, 25:2, 257-67.

Bosco, Anna, and Susannah Verney (2016). 'From Electoral Epidemic to Government Epidemic: The Next Level of the Crisis in Southern Europe', South European Society and Politics, 21:4, 383-406.

Canovan, Margaret (2004). 'Populism for Political Theorists?', Journal of Political Ideologies, 9:3, 241-52.

Costello, Anna, and Jason Osborne (2005). 'Best Practices in Exploratory Factor Analysis: Four Recommendations for Getting the Most From Your Analysis', Practical Assessment, Research \& Evaluation, 10:7, 1-9.

Cox, Gary (1997). Making Votes Count. Cambridge: Cambridge University Press.

Dahl, Robert (1994). 'A Democratic Dilemma: System Effectiveness versus Citizen Participation', Political Science Quarterly, 109:1, 23-34.

Di Stefano, Christine, Min Zhu, and Diana Mîndrilă (2009). 'Understanding and Using Factor Scores: Considerations for the Applied Researcher', Practical Assessment, Research \& Evaluation, 14:20, 1-11.

Fraile, Marta, and Michael Lewis-Beck (2010). 'Economic Voting in Spain: A 2000 Panel Test', Electoral Studies, 29:2, 210-20.

Gunther, Richard, and Larry Diamond (2003). 'Species of Political Parties: A New Typology', Party Politics, 9:2, 167-99.

Hawkins, Kirk, Scott Riding, and Cas Mudde (2012). Measuring Populist Attitudes. C\&M Working Paper (\#55), available at http://works.bepress.com/ cas_mudde/72/

Hawkins, Kirk, Madeleine Read, and Teun Pauwels (2017). 'Populism and its Causes', in Cristobal Rovira Kaltwasser, Paul Taggart, Paulina Ochoa Espejo, and Pierre Ostiguy (eds.), Oxford Handbook of Populism. Oxford: Oxford University Press, 267-88.

Hawkins, Kirk, Ryan Carlin, Levente Littvay, and Cristobal Rovira Kaltwasser (2018). The Ideational Approach to Populism: Concept, Theory and Analysis. Oxford: Routledge.

Hawkins, Kirk, Cristobal Rovira Kaltwasser, and Ioannis Andreadis (2018). 'The Activation of Populist Attitudes', Government and Opposition, 1-25. doi: 10.1017/gov.2018.23

Hellwig, Timothy (2008). 'Explaining the Salience of Left-right Ideology in Postindustrial Democracies: The Role of Structural Economic Change', European Journal of Political Research, 47:6, 687-709.

Hernández, Enrique, and Hanspeter Kriesi (2016). 'The Electoral Consequences of the Financial and Economic Crisis in Europe', European Journal of Political Research, 55:2, 203-24.

Hobolt, Sarah, and James Tilley (2016). 'Fleeing the Centre: The Rise of Challenger Parties in the Aftermath of the Euro Crisis', West European Politics, 39:5, 971-91.

Kang, Won-Taek (2004). 'Protest Voting and Abstention under Plurality Rule Elections. An Alternative Public Choice Approach', Journal of Theoretical Politics, 16:1, 79-102.

Kitschelt, Herbert (1988). 'Left-libertarian Parties: Explaining Innovation in Competitive Party Systems', World Politics, 40:2, 194-234. 
Kriesi, Hanspeter (2008). 'Political Mobilisation, Political Participation and the Power of the Vote', West European Politics, 31:1-2, 147-68.

Kriesi, Hanspeter (2014). 'The Political Consequences of the Economic Crises in Europe: Electoral Punishment and Popular Protest', in Nancy Bermeo and Larry Bartels (eds.), Mass Politics in Tough Times: Opinions, Votes and Protest in the Great Recession. Oxford: Oxford University Press, 297-333.

Lago, Ignacio, and Ferran Martinez (2011). 'Why New Parties?', Party Politics, 17: $1,3-20$.

Lavezzolo, Sebastian, and Luis Ramiro (2017). 'Stealth Democracy and the Support for New and Challenger Parties', European Political Science Review, 10: 2, 267-89.

Lewis-Beck, Michael (1986). 'Comparative Economic Voting: Britain, France, Germany, Italy', American Journal of Political Science, 30:2, 315-46.

Lewis-Beck, Michael, and Martin Paldam (2000). 'Voting: An Introduction', Electoral Studies, 19, 113-21.

Mair, Peter (2011). 'Bini Smaghi vs. the Parties: Representative Government and Institutional Constraints', Robert Schuman Centre for Advanced Studies and EU Democracy Observatory, European University Institute Working Paper no. 2011/22, Florence.

Marcos-Marne, Hugo, Carolina Plaza-Colodro, Margarita Gomez-Reino, Ivan Llamazares and Kirk Hawkins (2017). 'Populist Discourse, Attitudes and Discourse in Contemporary Spanish Politics', paper presented at ECPR General Conference in Oslo.

Mohrenberg, Steffen, Robert Huber, and Tina Freyburg (2017). 'Love at First Sight? Populism and Direct Democracy', paper presented at ECPR General Conference in Oslo.

Mood, Carina (2010). 'Logistic Regression: Why We Cannot Do What We Think We Can Do, and What We Can Do About It', European Sociological Review, 26:1, 67-82.

Mudde, Cas (2004). 'The Populist Zeitgeist', Government \& Opposition, 39:4, 541-63.

Mudde, Cas, and Cristobal Rovira Kaltwasser (2013). 'Exclusionary vs. Inclusionary Populism: Comparing Contemporary Europe and Latin America', Government \& Opposition, 48:2, 147-74.

Orriols, Lluis, and Guillermo Cordero (2016). 'The Breakdown of the Spanish Two-party System: The Upsurge of Podemos and Ciudadanos in the 2015 General Election', South European Society and Politics, 21:4, 469-92.

Pattie, Charles, and Ron Johnston (2001). 'Routes to Party Choice: Ideology, Economic Evaluations and Voting at the 1997 British General Election', European Journal of Political Research, 39:3, 373-89.

Rodon, Toni, and Maria Jose Hierro (2016). 'Podemos and Ciudadanos Shake up the Spanish Party System: The 2015 Local and Regional Elections', South European Society and Politics, 21:3, 339-57.

Rooduijn, Matthis (2018). 'What Unites the Voter Bases of Populist Parties? Comparing the Electorates of 15 Populist Parties', European Political Science Review, 10:3, 351-68.

Rovira Kaltwasser, Cristobal (2012). 'The Ambivalence of Populism: Threat and Corrective for Democracy', Democratization, 19:2, 184-208. 
Seawright, Jason, and John Gerring (2008). 'Case Selection Techniques in Case Study Research. A Menu of Qualitative and Quantitative Options', Political Research Quarterly, 61:2, 294-308.

Sola, Jorge, and Cesar Rendueles (2018). 'Podemos, the Upheaval of Spanish Politics and the Challenge of Populism', Journal of Contemporary European Studies, 26:1, 99-116.

Spruyt, Bram, Gil Keppens, and Filip Van Droogenbroeck (2016). 'Who Supports Populism and What Attracts People to it?', Political Research Quarterly, 69:2, 335-46.

Stanley, Ben (2008). 'The Thin Ideology of Populism', Journal of Political Ideologies, 13:1, 95-110.

Tavits, Margit (2006). 'Party System Change: Testing a Model of New Party Entry', Party Politics, 12:1, 99-119.

Torcal, Mariano (2014). 'The Incumbent Electoral Defeat in the 2011 Spanish National Elections: The Effect of the Economic Crisis in an Ideological Polarized Party System', Journal of Elections, Public Opinion \& Parties, 24:2, 203-21.

Van der Eijk, Cees, and Mark Franklin (1996). 'What We Have Learned About Voting Behavior and Elections', in Cees Van der Eijk and Mark Franklin (eds.), Choosing Europe? The European Electorate and National Politics in the Face of Union. Ann Arbor: University of Michigan Press, 391-408.

Van Hauwaert, Steven, and Stijn Van Kessel (2018). 'Beyond Protest and Discontent: A Cross-national Analysis of the Effect of Populist Attitudes and Issue Positions on Populist Party Support', European Journal of Political Research, 57:1, 69-92.

Vidal, Guillem (2018). 'Challenging Business as Usual? The Rise of New Parties in Spain in Times of Crisis', West European Politics, 41:2, 261-86.

Worthington, Roger, and Tiffany Whittaker (2006). 'Scale Development Research A Content Analysis and Recommendations for Best Practices', The Counseling Psychologist, 34:6, 806-38.

Yong, An Gie, and Sean Pearce (2013). 'A Beginner's Guide to Factor Analysis: Focusing on Exploratory Factor Analysis', Tutorials in Quantitative Methods for Psychology, 9:2, 79-94. 